\title{
A new allele of acid soil tolerance gene from a malting barley variety
}

\author{
Miao Bian ${ }^{1,4+}$, Xiaoli Jin ${ }^{2 \dagger}$, Sue Broughton ${ }^{3}$, Xiao-Qi Zhang ${ }^{4}$, Gaofeng Zhou ${ }^{3}$, Meixue Zhou ${ }^{5}$, Guoping Zhang ${ }^{2}$, \\ Dongfa Sun ${ }^{1 *}$ and Chengdao Li, $\mathrm{L}^{3,4^{*}}$
}

\begin{abstract}
Background: Acid soil is a serious limitation to crop production all over the world. Toxic aluminium (Al) cations in acid soil inhibit root growth and reduce yield. Although a gene tolerant to acid soil has been identified, it has not been used in malting barley breeding, which is partly due to the acid soil tolerance gene being linked to unfavorable malting quality traits.

Results: A Brazilian malting barley variety $\mathrm{Br} 2$ was identified as tolerant to acid soil. A doubled haploid (DH) population was developed from a cross between $\mathrm{Br} 2$ and the Australian acid-sensitive cultivar Hamelin. The DH population was tested for acid soil tolerance in native acid soil and a hydroponic system with pH 4.2, pH 4.2 $+\mathrm{Al}$ or $\mathrm{pH}$ 6.5, and genotyped using SSR, DArT and gene-specific markers. A single QTL was detected for all parameters related to acid soil tolerance. The QTL was mapped to the known HVMATE location on chromosome $4 \mathrm{H}$. Sequence alignment of the HVMATE gene identified 13 INDELs and 87 SNPS, where one SNP coded for a single amino acid difference between the two varieties. A gene-specific marker was developed to detect the single nucleotide polymorphism between Hamelin and Br2. This marker co-segregated with aluminium tolerance and accounted for $79 \%$ of phenotypic variation for acid soil tolerance.

Conclusion: The present study identified a novel source of acid soil/Al tolerance from a Brazilian malting barley cultivar Br2. This variety tolerated Al toxicity but was sensitive to low pH which is similar to most other Al-tolerant varieties. A gene-specific marker Cit7 was developed based on the HVMATE gene sequence. Cit7 will improve the efficiency of molecular-assisted selection of new barley varieties with tolerance to acid soil. Multiple alleles exist for the acid soil tolerance gene on chromosome $4 \mathrm{H}$, so a malting barley variety that tolerates acid soil could be developed by selecting suitable tolerant alleles. Tolerance to low pH may play an important role for barley to adapt to acid soils.
\end{abstract}

Keywords: Malting barley, Citrate transporter, Aluminium tolerance, Gene-specific marker

\section{Background}

Acid soil is a major limiting factor to plant production worldwide. It accounts for $30 \%$ of the total land area and $50 \%$ of the arable land [1] with loss of production equating to more than 600 million US dollars annually [2]. Aluminium (Al) toxicity limits growth and productivity of barley (Hordeum vulgare L.) on acid soils and thus restricts barley as a crop in many agricultural areas

\footnotetext{
* Correspondence: sundongfa@mail.hzau.edu.cn; c.li@murdoch.edu.au ${ }^{\dagger}$ Equal contributors

'College of Plant Science and Technology, Huazhong Agricultural University, Wuhan 430070, China

${ }^{3}$ Department of Agriculture \& Food WA, 3 Baron-Hay Court, South Perth, WA 6155, Australia

Full list of author information is available at the end of the article
}

$[2,3]$. The initial toxic effect of acid soil stunts and shortens root growth. The toxic aluminium (Al) cation in acid soil may also restrict water uptake and nutrient absorption, which eventually reduces plant production. Thus, root length is often selected as the phenotypic trait for aluminium toxicity tolerance $[4,5]$.

Genes related to Al tolerance are involved in multiple metabolic processes, including cell elongation and division, cell wall formation, oxidative stress, iron metabolism, signal transduction and other cellular mechanisms [6-8]. The expression of several $\mathrm{Al}$-induced genes, such as $\mathrm{AtBCB}$, parB, NtPOX and NtGDI1 in transgenic Arabidopsis plants resulted in better relative root growth under $\mathrm{Al}$ stress [9]. The secretion of organic anions such as citrate and malate from root apices plays an important role in excluding and 
detoxifying $\mathrm{Al}$ [10-12]. Of the many $\mathrm{Al}$-induced genes, ALMT and MATE- controlling malate and citrate extrusion respectively-have been reported as the Al-tolerant genes in many plants [13].

Barley is one of the most sensitive species to $\mathrm{Al}$ toxicity among small-grain crops $[14,15]$ but differences in $\mathrm{Al}$ tolerance exist among varieties. Al tolerance is controlled by one single gene or several QTLs depending on materials [2]. The major tolerance gene on chromosome $4 \mathrm{H}$ has been given various names according to its origin or tolerance to $\mathrm{Al}^{3+}$ toxicity or low $\mathrm{pH}$, which include Pht (low soil $\mathrm{pH}$ ) [16], Alp ( $\mathrm{Al}^{3+}$ in Dayton) [17], Alt $\left(\mathrm{Al}^{3+}\right.$ in WB229) and Alp3 $\left(\mathrm{Al}^{3+}\right.$ in Brindabella) [18, 19]. Ma et al. [20] reported that a QTL tightly linked to Al tolerance explained more than $50 \%$ of phenotypic variation in citrate secretion in a cross between an Al-resistant cultivar (Murasakimochi) and an Al-sensitive cultivar (Morex). This QTL was located at the same position of the major tolerance gene with the molecular marker Bmag353 tightly linked with citrate secretion [20]. Fine mapping combined with microarray analysis identified that HvAACT1, a MATE gene (also known as $H v M A T E)$, was responsible for the $\mathrm{Al}$-activated citrate secretion [21]. Heterologous expression of HvAACT1 in Xenopus oocytes showed transport activity for citrate and transgenic tobacco also showed higher citrate secretion when treated with $\mathrm{Al}$ [21]. Further study demonstrated that the relative expression of the HvMATE gene in the Alp locus on chromosome $4 \mathrm{H}$ was 30 -fold higher in Dayton (tolerant) than Gairdner (susceptible) [22]. The expression marker exhibited complete linkage with the Alp locus in the $\mathrm{DH}$ population, accounting for $72 \%$ of the variation for $\mathrm{Al}$ tolerance based on relative root growth under $\mathrm{Al}^{3+}$ stress [22]. These results further supported that HvMATE, a gene encoding a multidrug and toxic compound extrusion protein, is the candidate gene controlling $\mathrm{Al}$ tolerance on chromosome $4 \mathrm{H}$.

Despite progress in identifying the tolerance gene, development of malting barley variety that tolerates acid soil has been slow. This is partly due to the acid soil tolerance gene being linked to unfavorable malting quality traits. No acid soil tolerant malting barley cultivar has been reported. In the present study, we identified a malting barley variety from Brazil that tolerates $\mathrm{Al}$ toxicity. The tolerance gene was mapped to the same location as the HvMATE gene. Further sequencing and phenotyping analysis demonstrated that the tolerance gene is a new allele. One gene-specific molecular marker was developed and confirmed in the Hamelin/Br2 DH population. The phenotypic variation determined by the marker was also compared with other markers currently used for molecular-assisted selection.

\section{Results}

\section{Phenotyping and inheritance of Al tolerance in barley}

The Hamelin/Br2 DH population was assessed using acid soil and three hydroponic experiments: $\mathrm{pH} 4.2$, $\mathrm{pH} 4.2+\mathrm{Al}$ and $\mathrm{pH}$ 6.5. The two parents differed significantly in their Al tolerance. In the acid soil treatment, the female parent Hamelin had an average root length of $123 \mathrm{~mm}$, while the male parent $\mathrm{Br} 2$ had $191 \mathrm{~mm}$. In the hydroponic experiments, root growth of the two parents was similar in the $\mathrm{pH} 6.5$ treatment, with average root lengths of 88 and $92 \mathrm{~mm}$ for Hamelin and Br2, respectively. The solution $\mathrm{pH}$ of 4.2 significantly inhibited root growth of both varieties with average root lengths reduced to 47 and $41 \mathrm{~mm}$ for Hamelin and Br2, respectively. Addition of $\mathrm{Al}$ to the $\mathrm{pH} 4.2$ solution significantly reduced root growth in the sensitive cultivar (Hamelin) but had little effect on the tolerant cultivar $(\mathrm{Br} 2)$ : average root length of Hamelin decreased by more than $50 \%$ to $22 \mathrm{~mm}$, while Br2 only decreased by about $10 \%$ to $36 \mathrm{~mm}$.

Acidity and $\mathrm{Al}$ also had a significant effect on root growth of the DH lines with root length ranging from 46 to $405 \mathrm{~mm}$ in acid soil, 34 to $116 \mathrm{~mm}$ in the control solution (pH 6.5), 24 to $79 \mathrm{~mm}$ at $\mathrm{pH} 4.2$ and 14 to $41 \mathrm{~mm}$ at $\mathrm{pH} 4.2+\mathrm{Al}$ (Fig. 1). The root lengths of DH lines showed continuous distributions in all the hydroponic treatments. In the acid soil treatment, root lengths of DH lines could be divided into two separate groups, indicating one major
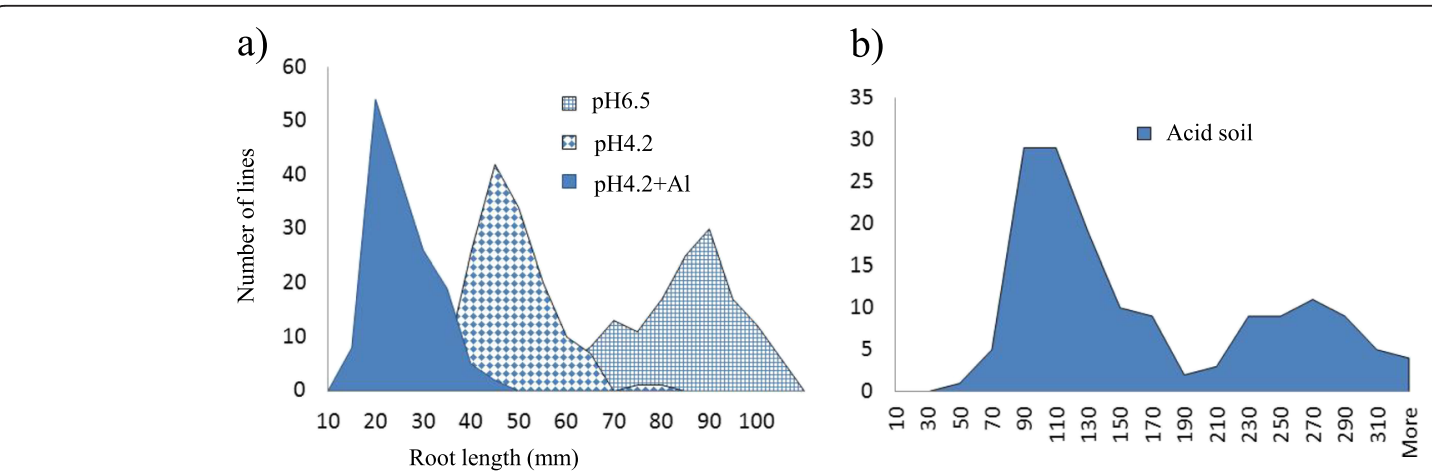

Fig. 1 Frequency distributions of root length for the Hamelin/Br2 DH population under acid soil, pH 6.5, pH 4.2 and pH $4.2+\mathrm{Al}$ treatments. a $\mathrm{pH} 6.5, \mathrm{pH} 4.2$ and $\mathrm{pH} 4.2+\mathrm{Al}$ treatments. b Acid soil treatment 
gene controlling acid tolerance. Chi-square analysis showed that the segregation did not fit the 1:1 ratio, due to the significant distortion of markers in the region for the $\mathrm{Al}$ tolerance gene (Additional file 1).

Root lengths of $\mathrm{DH}$ lines in solution $\mathrm{pH} 4.2+\mathrm{Al}$ had a significant correlation with those in the acid soil, explaining $62.6 \%$ of the phenotypic variation in root length in the acid soil treatment. This result suggests that the hydroponic experiment with $\mathrm{Al}$ was consistent with the acid soil experiment. However, root lengths of $\mathrm{DH}$ lines grown at solution $\mathrm{pH} 4.2$ had no correlation with those in the acid soil $\left(P=0.025, R^{2}=0.0328\right)$.

A scatter graph was constructed using the phenotypic data from the acid soil and $\mathrm{pH} 4.2+\mathrm{Al}$ treatments (Fig. 2). All DH lines could be clearly classified into two groups, with red scatters signifying the sensitive group and blue scatters representing the tolerant group (102 red, 52 blue, four data missing). However, Chi square analysis showed that the segregation did not fit the 1:1 ratio $(\chi 2=16.23, \alpha=5 \%)$. An additional regression analysis also showed that the phenotype data collected from acid soil and $\mathrm{pH} 4.2+\mathrm{Al}$ treatments were significantly correlated with each other $\left(\mathrm{P}<0.0001, R^{2}=0.626\right)$. This suggests that the acid soil/Al tolerance in $\mathrm{Br} 2$ is probably controlled by a major gene.

\section{Linkage map construction and QTL analysis}

Thirty-seven lines selected from the DH population were genotyped using DArT. In total, 446 commonly-used SSR markers and 388 DArT markers were tested for polymorphism, in which44 SSR markers and 258 DArT markers were mapped to seven chromosomes (Additional file 2). One major QTL for acid soil tolerance was detected on chromosome $4 \mathrm{H}$ by preliminary QTL analysis (data not shown). Based on the preliminary analysis, six polymorphic markers in the QTL region were selected to map the whole population and the marker order was similar to the previously reported consensus map (Fig. 3) [23]. QTL analysis showed that the same QTL controls root growth in acid soil and $\mathrm{pH} 4.2+\mathrm{Al}$ solution (Fig. 4b). The nearest marker Bmag353 explained $67.5 \%$ of the phenotype variation in root length at $\mathrm{pH} 4.2+\mathrm{Al}$ and $72.4 \%$ in acid soil, $78.1 \%$ of average root length at $\mathrm{pH} 4.2+\mathrm{Al}$ and in acid soil, and $55.4 \%$ of relative root length at $\mathrm{pH} 4.2+$ $\mathrm{Al}$ (Table 1). When DH lines were grouped into tolerant and sensitive, $88.1 \%$ of the variation in tolerance was explained by Bmag353 using single marker regression analysis $(\mathrm{P}<0.001)$. Based on previous studies, Bmag353 and Bmac310 were the common markers associated with the HvMATE acid soil tolerance gene [24, 22]. Thus, the tolerant cultivar Br2 may share the same tolerance gene identified in previous studies.

\section{Gene-specific marker development and association analysis}

The HvMATE gene contains 13 exons and 12 introns with a full length of 12,257 bp (Fig. 5a). Forty-four pairs of primers covering the whole gene were designed to amplify the fragments of $H v M A T E$ gene in Hamelin and Br2 (Additional file 3). The PCR product size of these primers varied from $200 \mathrm{bp}$ to $500 \mathrm{bp}$. Sixteen pairs of these primers were polymorphic between Hamelin and Br2 (Table 2). One marker Cit7 (Cit7F: 5-GCAGCC AAGACCTTGAGAAAGC-3 and Cit7R: 5-GCCTGAAC TAGCCCGAGAAATG-3) designed from the coding region of HvMATE gene and 54 other polymorphic SSR markers were used to construct the linkage map of the full population. The results showed that the gene-specific marker Cit7 was located between SSR markers Bmag353 and Bmac310 on chromosome $4 \mathrm{H}$ (Fig. 3). When Cit7

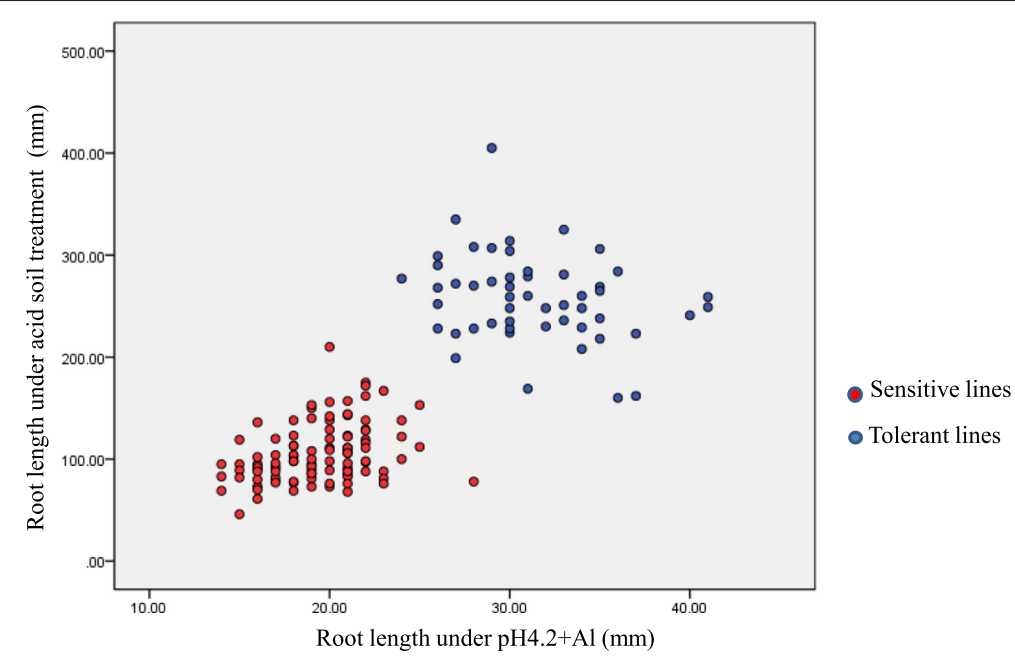

Fig. 2 Scatter graph showing Hamelin/Br2 DH lines could be classified into two groups 


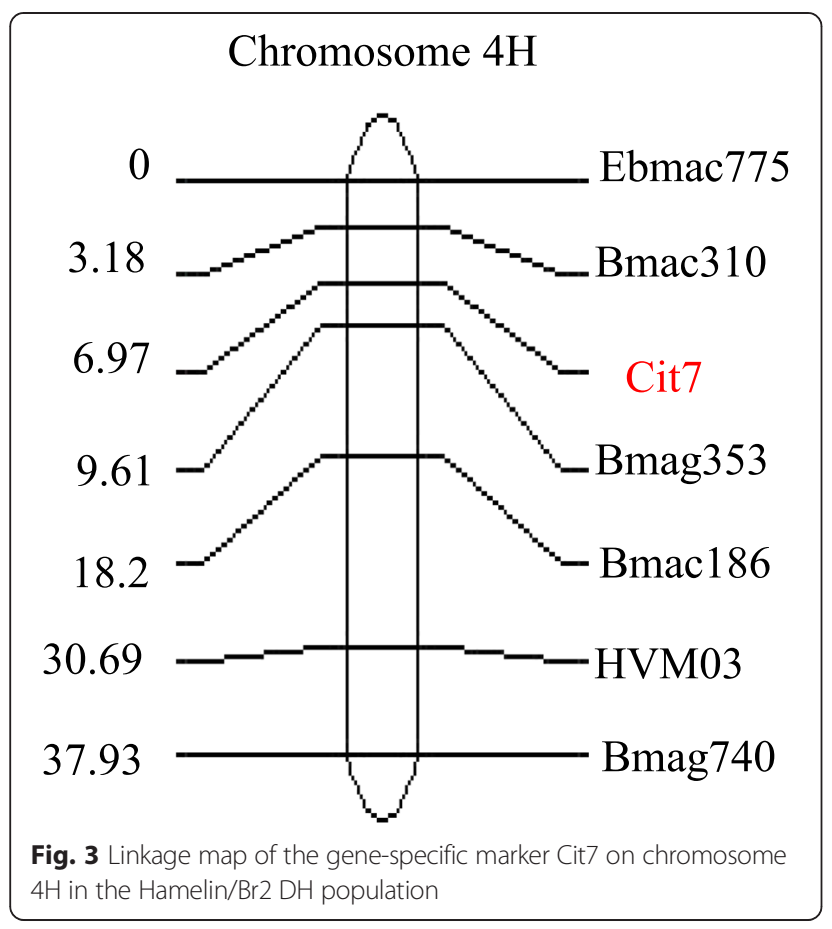

was integrated into the chromosome $4 \mathrm{H}$ linkage map, the phenotypic variation explained by the QTL increased for all traits (Fig. 4a and Table 1). For example, $82 \%$ of the variation in root length in acid soil was explained by the QTL compared to $73.4 \%$ by other markers previously (Table 1).

\section{Sequence assembly, alignment and new allele identification}

The sequences of Br2, Hamelin and Svanhals were assembled and aligned using software BioEdit (http:// www.mbio.ncsu.edu/BioEdit) with default parameters. The sequences were compared with sequences from Morex, Murasakimochi and Haruna Nijo [25, 21]. There were 14 indels and 86 SNPs between the tolerant and sensitive cultivars (Additional file 4). Of which, 87 variations differed from these alleles reported elsewhere [25, 21]. The sequence variations varied from 1 SNP to $29 \mathrm{bp}$. Six indels located in the $5^{\prime}$ upstream region, one indel (12619-12620 bp) and one SNP (12660 bp) are located on the 3' UTR. Five indels are located on the downstream of

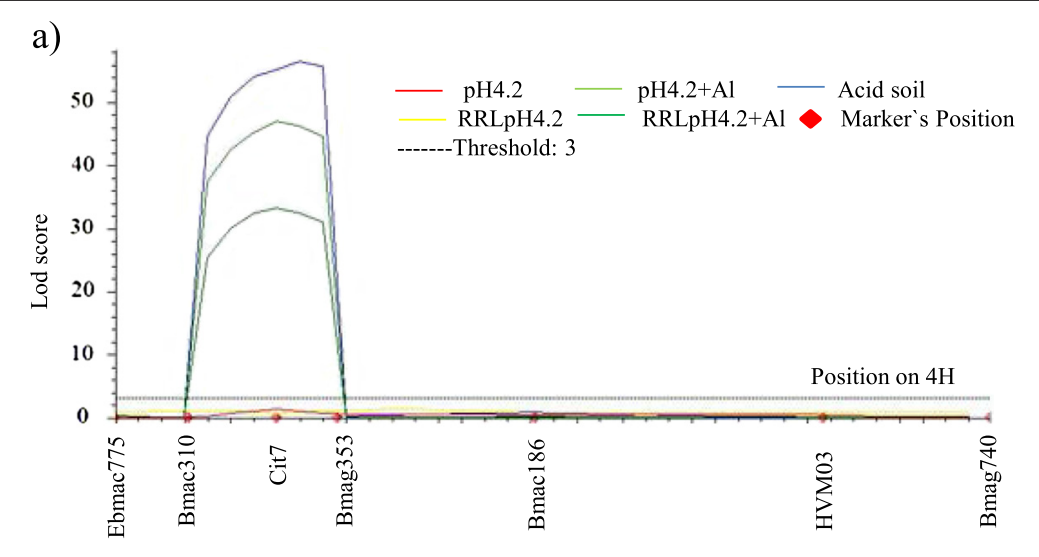

b)

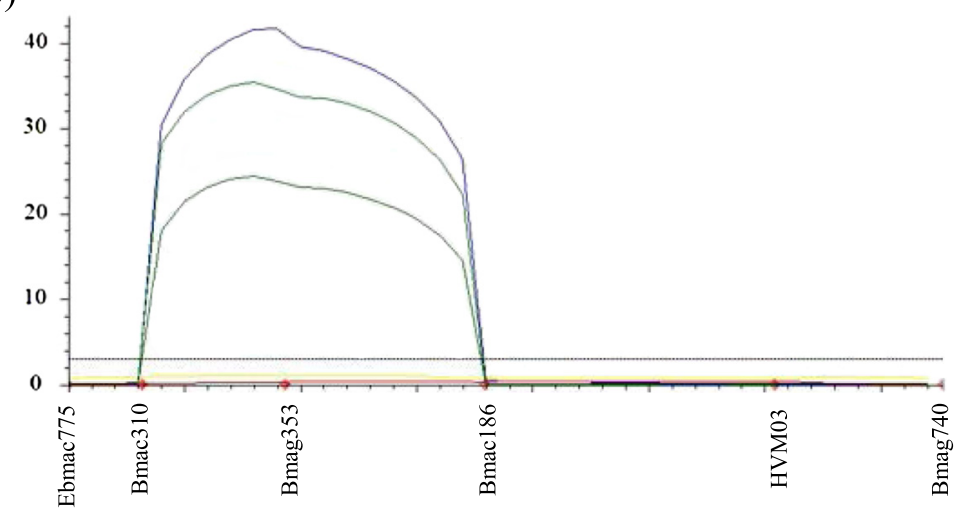

Fig. 4 QTL and LOD score for acid soil tolerance on chromosome 4H in the Hamelin/Br2 population. a commonly-used SSR markers and gene-specific marker Cit7 (RRLpH4.2 + Al: relative root length of pH4.2 + Al, RRLpH4.2: relative root length of pH4.2). b commonly-used SSR markers 
Table 1 Comparison of Cit7 and Bmag353 on explained phenotypic variations (EPV) on acid soil, $\mathrm{pH} 4.2+\mathrm{Al}$ and relative root length of $\mathrm{pH} 4.2+\mathrm{Al}(\mathrm{RRL})$ based on interval QTL analysis and single marker regression analysis

\begin{tabular}{|c|c|c|c|c|c|c|}
\hline \multirow[t]{2}{*}{ Traits } & \multicolumn{2}{|c|}{ Before add Cit7 } & \multicolumn{2}{|c|}{ After add Cit7 } & \multirow{2}{*}{$\frac{\text { Cit7 }}{\text { EPV (\%) }}$} & \multirow{2}{*}{$\frac{\text { Bmag353 }}{\text { EPV (\%) }}$} \\
\hline & $\overline{L O D}$ & EPV (\%) & $\overline{L O D}$ & $\overline{E P V}(\%)$ & & \\
\hline $\mathrm{pH} 4.2+\mathrm{Al}$ & 35.4 & 68.5 & 47.0 & 75.5 & 75.7 & 67.5 \\
\hline Acid soil & 41.6 & 73.4 & 56.5 & 82.0 & 79.0 & 72.4 \\
\hline RRL & 24.4 & 55.5 & 33.3 & 63.0 & 63.0 & 55.4 \\
\hline
\end{tabular}

3' UTR. Thus, the tolerance gene from $\mathrm{Br} 2$ represents a new allele.

Further sequence analysis demonstrated that Cit7 covers part of the sequence of the HvMATE gene exon 3 (7255-7461 bp) and part of the sequence of exon 4 (7572-7765 bp) (Fig. 5). One SNP (T (sensitive)-G (tolerant)) was detected between sensitive and tolerant cultivars (Fig. 6). Online translation software, expasytranslate tool (available from http://web.expasy.org/ translate/), was used for DNA translation under default parameters. The results showed that the SNP coded for a single amino acid difference (L (172)-V) between the sensitive and tolerant cultivars (Fig. 6).

\section{Discussion}

Tolerance to low $\mathrm{pH}$ and Al toxicity

Acid soil limits plant growth through $\mathrm{pH}$ toxicity and metallic toxicity, especially $\mathrm{Al}$ [12]. To investigate possible toxicity mechanisms in the tolerant cultivar used in this experiment, three hydroponic treatments were employed to evaluate the effects of low $\mathrm{pH}$ and low $\mathrm{pH}+\mathrm{Al}$ on root growth. The results showed that low $\mathrm{pH}$ had a significant impact on root growth. The combination of low $\mathrm{pH}$ and $\mathrm{Al}$ had even larger effects on root growth (Fig. 1). Our results are consistent with those previously reported [14, 26, 27]. Both parents were sensitive to low $\mathrm{pH}$ and root length decreased from about 90 to $40 \mathrm{~mm}$ when the solution $\mathrm{pH}$ decreased from 6.5 to 4.2. However, $\mathrm{Br} 2$ had higher $\mathrm{Al}$ tolerance with only $10 \%$ further reduction in root length after the addition of $\mathrm{Al}$ compared to a $50 \%$ reduction in Hamelin. Root growth in $\mathrm{DH}$ lines showed similar trends with low $\mathrm{pH}$ affecting root growth of nearly all the lines and $\mathrm{Al}$ only affecting sensitive lines. The difference in low $\mathrm{pH}$ tolerance and $\mathrm{Al}$ tolerance has also been reported elsewhere. For example, Kidd and Proctor [28] reported that Holcus lanatus L. and Betula pendula Roth races collected from different sites differed in $\mathrm{pH}$ tolerance and $\mathrm{Al}$ tolerance. The authors concluded that the races collected from acid organic soil were tolerant to low $\mathrm{pH}$, while

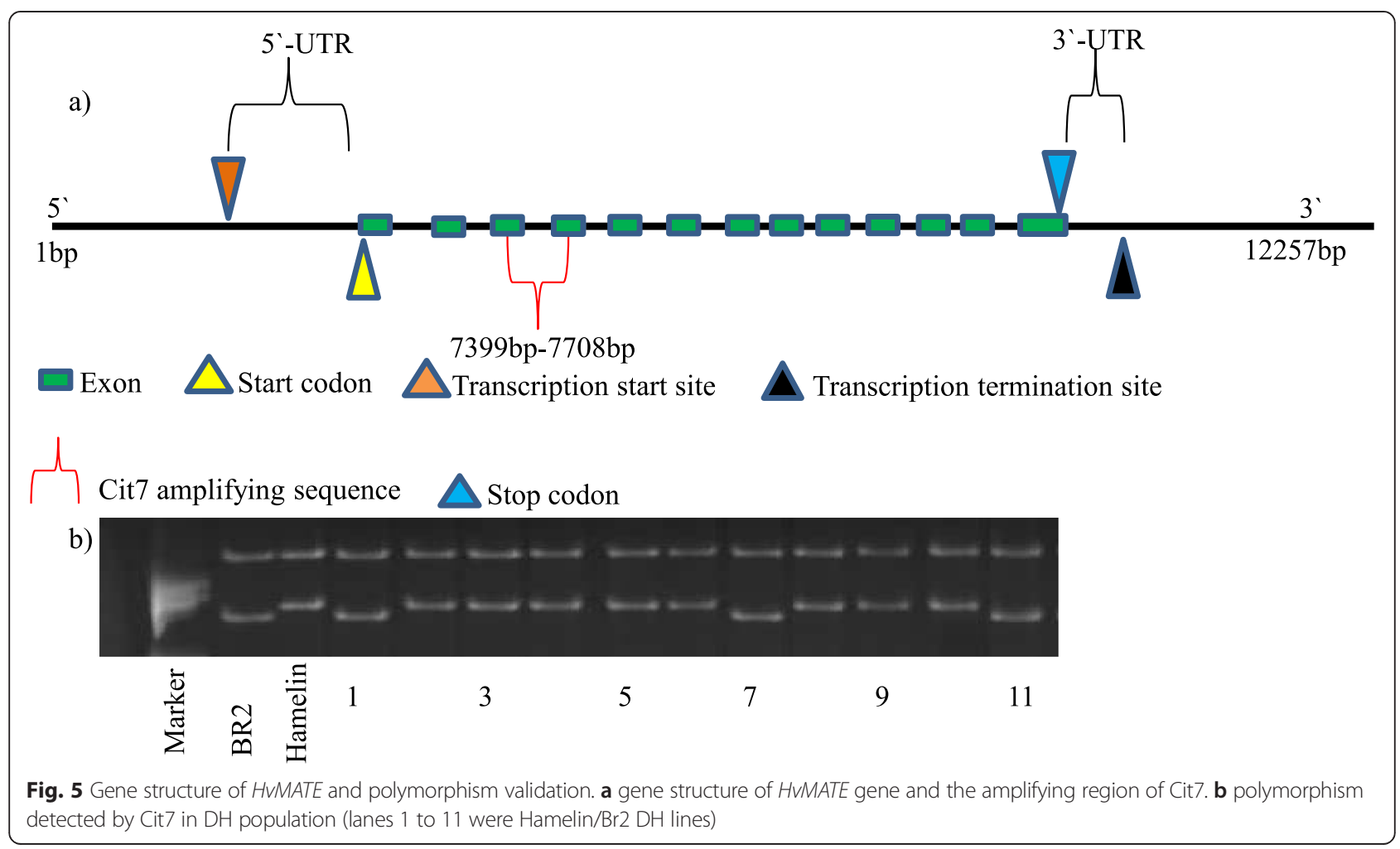


Table 2 Polymorphic gene-specific markers derived from the HVMATE gene between Hamelin and $\mathrm{Br} 2$

\begin{tabular}{|c|c|c|c|c|}
\hline Marker name & Product length (bp) & Annealing temperature $\left({ }^{\circ} \mathrm{C}\right)$ & Polymorphic type & Primers \\
\hline \multirow[t]{2}{*}{ HvMATE-21indel } & 497 & 62 & Agarose & F: GCTAGGGCTTGAAAACTGTTTG \\
\hline & & & & R: GACGAACTGTACGATGATGATGC \\
\hline \multirow[t]{2}{*}{ D0 } & 352 & 55 & Agarose & F: GCCACGCCTTACAGTAAAGAAC \\
\hline & & & & R: CCTAGCTATCTCAAGTTGGCTTAC \\
\hline \multirow[t]{2}{*}{ Cit7 } & 312 & 67 & SSCP & F: GCAGCCAAGACCTTGAGAAAGC \\
\hline & & & & R: GCCTGAACTAGCCCGAGAAATG \\
\hline \multirow[t]{2}{*}{ Cit14 } & 225 & 58 & SSCP & F: TCGGGTATTGGAGTTAGAAGGG \\
\hline & & & & R: CGGGCACATTTGATGCAAGGAT \\
\hline \multirow[t]{2}{*}{ Cit16 } & 205 & 55 & SSCP & F: CCCGAGTTATGTCATTITTCCTCTC \\
\hline & & & & R: GGGCCTGGTTGGGCCTTAT \\
\hline \multirow[t]{2}{*}{ Cit6 } & 225 & 55 & SSCP & F: ACCTTCCGTGACATCTGCTCTA \\
\hline & & & & R: ATCGGTGAGTCCTGGAATAGTG \\
\hline \multirow[t]{2}{*}{ U5 } & 491 & 55 & SSCP & F: CACACAACTGGAAAACAACTACC \\
\hline & & & & R: GGATAAAACTTCAGTGCGACG \\
\hline \multirow[t]{2}{*}{ Cit1501 } & 332 & 55 & SSCP & F: GAAGGGGCCTATTGCTTCAC \\
\hline & & & & R: CACCCATAAGTTGTGGTTCGG \\
\hline \multirow[t]{2}{*}{ Cit19 } & 355 & 67 & SSCP & F: TGGTGAAACGGGCATGTCTC \\
\hline & & & & R: GAAACCAGGTATATTGCAAGAGC \\
\hline \multirow[t]{2}{*}{$U 12 f+U 11 r$} & 726 & 55 & Agarose & F: TCGTCAATCGCAACTCTCAGA \\
\hline & & & & R: CATATCGTTTGTCGTATCACGC \\
\hline \multirow[t]{2}{*}{ U4 } & 404 & 55 & SSCP & F: CAAGTGTGAAATAGAGAGTCGGTAG \\
\hline & & & & R: CGCAAGAACATITITGTCACG \\
\hline \multirow[t]{2}{*}{ D5 } & 453 & 55 & SSCP & F: CGGGTATTGGAGTTAGAAGGG \\
\hline & & & & R: GCTATAAAGTCCACGCTATGCAG \\
\hline \multirow[t]{2}{*}{ D3 } & 448 & 58 & SSCP & F: CTCCTGCGAGGCAGATGAG \\
\hline & & & & R: CTCGCTCTCCCTAATGGTGG \\
\hline \multirow[t]{2}{*}{ D01R } & 362 & 60 & SSCP & F: GCTCAACCAGACTCAGGTAAGC \\
\hline & & & & R: CCAAACAGGGCCTAAGCTTC \\
\hline \multirow[t]{2}{*}{ D202rr } & 474 & 60 & SSCP & F: GTCTTCAACAGCATGATTAAGGTC \\
\hline & & & & R: CAAACCTAGCACTATTCGGGTG \\
\hline \multirow[t]{2}{*}{ D4FF } & 440 & 58 & SSCP & F: CAATCCTTGCATCAAATGTGC \\
\hline & & & & R: GGCCCTAAGATAGAAGCACAAG \\
\hline
\end{tabular}

those from acid mineral soils were tolerant to Al but not necessarily tolerant to low $\mathrm{pH}[28]$.

Tolerance to acid soil may be a combination of low $\mathrm{pH}$ tolerance and $\mathrm{Al}$ tolerance. In the present study, all of the $\mathrm{DH}$ lines were severely affected by low $\mathrm{pH}$ and no QTL was detected for root length. The major difference between $\mathrm{DH}$ lines was $\mathrm{Al}$ tolerance with a major QTL being detected for root length and relative root length in the $\mathrm{pH} 4.2+\mathrm{Al}$ treatment. The QTL was located in the same position as that for root growth under acid soil conditions. The results indicate that, compared with low $\mathrm{pH}, \mathrm{Al}$ toxicity is better for differentiating $\mathrm{DH}$ lines in this population. Since most of the current acid soil tolerant varieties tolerate $\mathrm{Al}$ toxicity but not necessarily low $\mathrm{pH}$, the search for germplasm tolerant to low $\mathrm{pH}$ may be the key for future breeding programs targeting acid soil tolerance.

\section{A single gene controls tolerance to Al toxicity in the tolerant cultivar $\mathrm{Br} 2$}

It is still not fully understood whether $\mathrm{Al}$ tolerance in plants is a quantitative or qualitative trait [12]. In some species such as rice [29-31], maize [32] and triticale [33], the tolerance has been identified as quantitative, while in other species such as wheat [34], pea [35] and chickpea [36], Al tolerance was inherited monogenetically. Within 


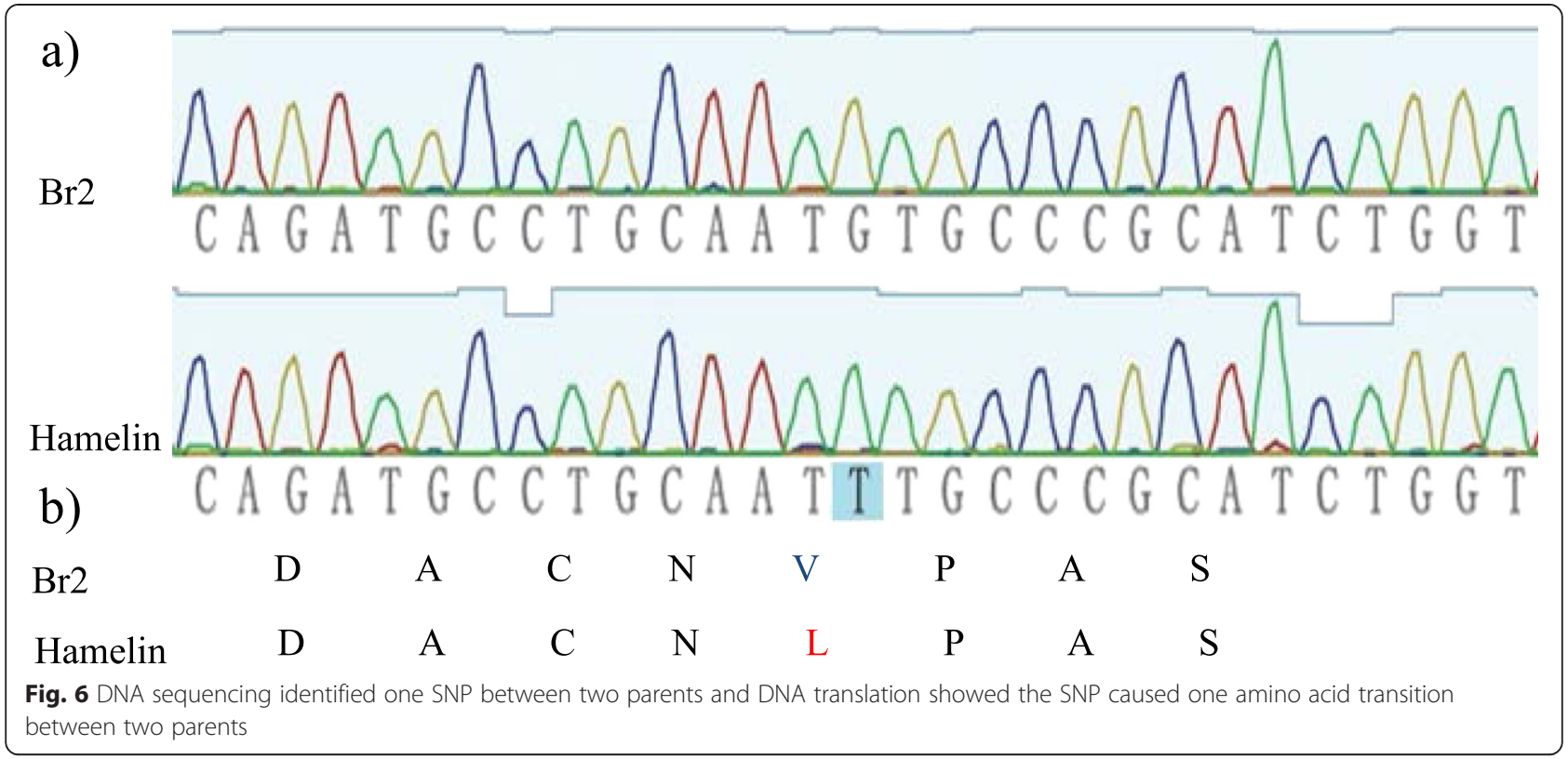

different genotypes in same species, the inheritance can differ [37]. Most studies have shown that Al tolerance in barley is controlled by a single gene $[2,17,16]$; however, there are some reports that suggest that $\mathrm{Al}$ tolerance in barley is a quantitative trait. For example, Navakode et al. [38] reported that $\mathrm{Al}$ tolerance was controlled by three QTLs located on chromosomes $2 \mathrm{H}, 3 \mathrm{H}$ and $4 \mathrm{H}$. Two of these QTLs (on chromosomes $2 \mathrm{H}$ and $4 \mathrm{H}$ ) were detected under $10 \mu \mathrm{M} \mathrm{Al}$, while one was found on chromosome $3 \mathrm{H}$ at $20 \mu \mathrm{M} \mathrm{Al}$ [38]. In the present study, the scatter graph (Fig. 2) showed two distinct groups, indicating that $\mathrm{Al}$ tolerance in the tolerant cultivar $\mathrm{Br} 2$ was a qualitative trait. Our results support previous studies that suggest that only one gene is responsible for $\mathrm{Al}$ tolerance $[17,16]$. Segregation distortion is a common phenomenon in barley which skews the frequency of alleles from their Mendelian expectations [39]. The distortion of markers in the region of the tolerance gene (Additional file 1) in this DH population caused the biased segregation ratio of the tolerant to the sensitive, which did not fit 1:1 $\left(x^{2}=16.23\right)$.

\section{QTL analysis and marker efficiency}

Aluminium/acid soil toxicity is caused by excessive exposure to soluble toxic metallic elements and lack of sufficient essential elements in low pH conditions [14]. Bmac310 and Bmag353 are the most commonly-used SSR markers in barley acid soil studies. Raman et al. [40] reported that these two markers were tightly linked with the Alp locus. The authors also pointed out that Bmac310 and Bmag353 could be broadly used in marker-assisted selection for breeding [40]. Wang et al. [22] also validated a candidate gene HvMATE on chromosome $4 \mathrm{H}$ and found that markers ABG715, Bmag353, GBM1071, GWM165 and
HvGABP had complete linkage with the locus. The same gene was validated by Furukawa et al. [21]. Compared with the commonly-used SSR markers Bmac310 and Bmag353, the new marker Cit7 is more precise in explaining phenotypic variation under acid soil treatments (Table 1 ).

\section{Single nucleotide polymorphism can affect gene function}

After decades of studies on acid soil/Al tolerance in plants, several genes controlling $\mathrm{Al}$ tolerance have been detected, such as TaALMT in wheat [34], ScAACT1 in rye [41], AtALMT1 in Arabidopsis [42], HvMATE in barley [21] and ZmMATE1 in maize [43]. However, it is still not clear which gene sequence variations affect gene expression. Sasaki et al. [44] reported that variation in the sequence upstream of TaALMT gene can affect gene expression. More recently, Fujii et al. [25] reported that one $1 \mathrm{~Kb}$ insertion upstream of the gene sequence was detected in some tolerant Asian accessions which was shown to have promoter activities. In contrast, Maron et al. [45] reported that the phenotypic variation between one Al-tolerant parent and one sensitive parent maize was caused by a different copy-number on the ZmMATE1 gene.

In the present study, one SNP in the coding region of HvMATE was detected by the gene-specific marker Cit7 between the sensitive and tolerant cultivars and validated by DNA sequencing. In order to validate Cit7 in diverse germplasm, 56 other accessions (Additional file 5) collected from different parts of the world were used to conduct the association analysis. Result showed the polymorphism was significantly correlated with phenotypic variation under acid soil treatment $\left(P=0.0057, R^{2}=0.129\right)$. DNA translation identified one amino acid change between the sensitive and tolerant cultivars. However, the $1 \mathrm{~Kb}$ insertion in the 
upstream of the gene sequence for $\mathrm{Al}$ tolerance in some Asian tolerant accessions [25] was not detected in $\mathrm{Br} 2$. It is likely that the amino acid change affects gene function $[46,47]$, which has been confirmed in several studies $[48,49]$. For example, Doyle and Amasino [48] reported one mutant clf-59, the protein of which contained one pro-to-ser amino acid transition in a cys-rich region. The mutant was reported to elevate levels of trimethylation on lysine 27 of histone $\mathrm{H} 3$ (H3K27me3) and repressed FLC (FLOWERING LOCUS C) during vernalization [48]. In barley, Yang et al. [50] validated that the Thr/Ala-233 and Ala/Ser-885 substitutions in the limit dextrinase gene were associated with enzyme thermostability using 60 barley genotypes from different parts of the world. More evidence is needed to prove its role in gene function.

\section{Conclusions}

In this study, one malting barley variety $\mathrm{Br} 2$ from Brazil was identified to be $\mathrm{Al}$ tolerance and the corresponding gene was validated to be $H v M A T E$ on chromosome $4 \mathrm{H}$. Multiple sequence variations were identified and these novel variations provide rich resources for selection of tolerant alleles in the breeding programs. One genespecific marker Cit7 was developed and validated to increase phenotypic variation efficiency explained by QTL. The marker could be used for marker-assisted selection in breeding of acid soil tolerant cultivars in the future.

\section{Methods}

\section{Plant materials}

A double haploid ( $\mathrm{DH}$ ) population derived from a cross of Hamelin/Br2 was generated from anther culture. This population consisted of $158 \mathrm{DH}$ lines. The Al-sensitive female parent cultivar Hamelin is from the Western Australian barley breeding program and the male parent Br2 is a malting barley variety from Brazil. Preliminary screening demonstrated that Br2 tolerates acid soil. Additional fifty-six accessions were collected from different parts of the world for validation of the gene-specific markers (Additional file 5). This study does not involve humans, human data or animals.

\section{Phenotyping for acid soil/aluminium toxicity tolerance Soil method}

Natural acid soil was collected from the 10-30 cm layer. Soil pH was 4.2 with soluble aluminium of $8.1 \mathrm{mg} / \mathrm{kg}$. For the control treatment, lime was added to the same soil to adjust the $\mathrm{pH}$ to 6.5. Five seeds of each line were sown in pots containing acid soil or limed acid soil. Seedlings were removed from the soil for root length measurements one week after sowing. Root length was used as a parameter for acid soil tolerance. The experiment was conducted in a glasshouse and each sample was replicated three times.

\section{Hydroponic method}

Three hydroponic treatments were used to screen barley for acid/aluminium tolerance: (1) control treatment at $\mathrm{pH} 6.5,(2)$ acid treatment at $\mathrm{pH} 4.2$, and (3) acid + aluminium treatment at $\mathrm{pH} 4.2$ with $2 \mathrm{ppm}$ aluminium. All three treatments contained the same nutrient solution with the following macronutrients $(\mathrm{mM})$ : $\mathrm{CaCl}_{2} .2 \mathrm{H}_{2} \mathrm{O}, 4.0 ;\left(\mathrm{NH}_{4}\right)_{2} \mathrm{SO}_{4}, 0.1 ; \mathrm{KNO}_{3}, 6.5 ; \mathrm{MgCl}_{2} \cdot 6 \mathrm{H}_{2} \mathrm{O}$, 2.5; $\mathrm{NH}_{4} \mathrm{NO}_{3}, 0.4$ and the following micronutrients $(\mu \mathrm{M}): \mathrm{NaH}_{2} \mathrm{PO}_{4}, 13 ; \mathrm{MnSO}_{4} . \mathrm{H}_{2} \mathrm{O}, 2 ; \mathrm{CuSO}_{4} .5 \mathrm{H}_{2} \mathrm{O}, 0.3$; $\mathrm{ZnSO}_{4} .7 \mathrm{H}_{2} \mathrm{O}, 0.8 ; \mathrm{H}_{3} \mathrm{BO}_{3}, 10 ; \mathrm{Na}_{2} \mathrm{MoO}_{4} .2 \mathrm{H}_{2} \mathrm{O}, 0.1$ and $\mathrm{FeSO}_{4} .7 \mathrm{H}_{2} \mathrm{O}, 10$. In the acid + aluminium treatment, $\mathrm{Al}$ was included as $\mathrm{AlCl}_{3} \cdot 6 \mathrm{H}_{2} \mathrm{O}$ at $74 \mu \mathrm{M}$ (2 ppm Al). The solution $\mathrm{pH}$ was adjusted to either 6.5 or 4.2 using $\mathrm{KOH}$ or $\mathrm{HCl}$ and constantly monitored for $\mathrm{pH}$ changes.

Approximately 50 seeds of each line were placed in a $9 \mathrm{~cm}$ Petri-dish with $5 \mathrm{ml}$ deionised (DI) water. Extra seeds of each line were included (approximately double) to ensure there were enough seeds with similar root lengths for the experiment. The Petri-dishes were wrapped in Clingfilm in bundles of 10-20 to incubate the seeds in the dark for $45 \mathrm{~h}$ at $4{ }^{\circ} \mathrm{C}$, followed by $47-48 \mathrm{~h}$ at $18{ }^{\circ} \mathrm{C}$. Germinated seeds were placed into allocated positions on the grid trays ensuring that roots were kept moist. The seeds were positioned so that the roots faced downwards into the nutrient solution. Seeds with root lengths between 4 and $7 \mathrm{~mm}$ were selected preferentially. Replicate 1 was sown on the first day and Replicate 2 on the second day. Germinated seeds were stored at $4{ }^{\circ} \mathrm{C}$ between sowing dates. The grid trays containing germinated seeds were placed into the three treatment solutions and grown at $20 / 15{ }^{\circ} \mathrm{C}$ (day/night) in a controlled environment room with a 12-h day length. All solutions bubbled gently with air stones and aquarium pumps to aerate the solutions and prevent stagnation. The $\mathrm{pH}$ of the solutions was checked daily and adjusted as necessary using either $\mathrm{KOH}$ or $\mathrm{HCl}$. Dosing meters, which dosed acid or alkali, were also used to maintain $\mathrm{pH}$ at desired levels. Root lengths were measured after 7 days. The $\mathrm{pH}$ effect was calculated as the percentage root length reduction at $\mathrm{pH} 4.2$ over $\mathrm{pH}$ 6.5. The Al effect was calculated as the percentage root length reduction at $\mathrm{pH} 4.2+\mathrm{Al}$ over $\mathrm{pH} 4.2$.

\section{Genotyping the DH population}

Forty DH lines were initially selected for genotyping based on phenotypic data with each $20 \mathrm{DH}$ lines representing the tolerant and susceptible groups using Diversity Arrays Technology (DArT) (http://www.diversityarrays.com; barley version 2.0 array). Three DH lines with poor data quality were not included in further analyses. In addition, 446 commonly-used SSR markers were synthesized using information from previous publications [51-60, 23] and used to screen polymorphic markers to map acid soil 
tolerance using all $158 \mathrm{DH}$ lines from the Hamelin/Br2 population.

Forty-four primers (Additional file 3) were synthesized from contig_51011 containing the HvMATE gene from the International Barley Genome Sequencing Consortium (http://webblast.ipk-gatersleben.de/barley/viroblast.php) using Primer Premier 5.0 (Premier Biosoft International, Palo Alto, CA).

\section{DNA extraction, PCR reaction and sequencing}

Young leaves from two-week-old seedlings were cut with scissors and stored at $-80{ }^{\circ} \mathrm{C}$. Genomic DNA was extracted from young leaves using the phenol/chloroform method [50]. PCR products were loaded on $2 \%$ agarose, $6 \%$ polyacrylamide and $12 \%$ SSCP/TBE gels, stained with ethidium bromide and visualized under UV light to detect polymorphisms in different cultivars. The SSCP method followed previously described procedures [61, 62] (acrylamide/bisacrylamide ratio of 37.5:1) in cold $0.5 \times \mathrm{TBE}$ and run at room temperature for 24-36 h. PCR products were sequenced directly in both directions using the Big-Dye ${ }^{\text {Tx }}$ Terminator method on an Applied Biosystems 3730 DNA Sequencer (SABC, Murdoch University, Western Australia) after purification with a QIAquick PCR purification kit (Qiagen).

\section{Data analysis}

Root length in acid soil, $\mathrm{pH} 4.2, \mathrm{pH} 4.2+\mathrm{Al}$, relative root length of $\mathrm{pH} 4.2$ (root length under $\mathrm{pH} 4.2$ divided by root length under $\mathrm{pH}$ 6.5), relative root length of $\mathrm{pH} 4.2+\mathrm{Al}$ (root length under $\mathrm{pH} 4.2+\mathrm{Al}$ divided by root length under $\mathrm{pH}$ 6.5) were used for the QTL analysis. Association of the markers with traits was calculated by PASW Statistics v.18 (SPSS Inc., Chicago, USA). Geneious software package Geneious v5.1 (http://www.geneious.com) and BioEdit (http://www.mbio.ncsu.edu/BioEdit) with default parameters were used for DNA sequence editing, comparison and alignment. Linkage map construction and QTL analysis were performed using QTL IciMapping Version 3.2 at $\mathrm{LOD}=3.0$ and Kosambi map unit function [63-66].

\section{Availability of supporting data}

All the supporting data are included in 5 additional files. DNA sequencing data is deposited in GeneBank with Accession Numbers: KT168175, KT168176 and KT168177.

\section{Additional files}

Additional file 1: Segregation distortion of markers in the region of Al tolerance gene on $4 \mathrm{H} ;{ }^{*}$ means significance at $0.05,{ }^{* *}$ means significance at $\mathbf{0 . 0 1}$. (DOCX $34 \mathrm{~kb})$

Additional file 2: Linkage map of DArT and SSR markers in Hamelin/Br2 DH population. (PPTX $814 \mathrm{~kb}$ )
Additional file 3: Primers' position and coverage of HvMATE gene (Primers' names are highlighted in red). F: forward primer position (bp), R: reverse primer position (bp). (PPTX 369 kb)

Additional file 4: SNP and INDEL of HvMATE gene in 6 barley cultivars. (DOCX $48 \mathrm{~kb}$ )

Additional file 5: Fifty-six barley accessions and their origins. (DOCX $37 \mathrm{~kb}$ )

\section{Abbreviations}

Al: Aluminium; ALMT1: Aluminium-activated malate transporter 1; AtBCB: Arabidopsis blue copper binding protein; parB: Tobacco glutathione S-transferase; NtPOX: Tobacco peroxidase; NtGDI1: Tobacco GDP-dissociation inhibitor; clf-59: Curly leaf; FLC: Flowering locus C; L: Leucine; V: Valine; SNP: Single nucleotide polymorphism; HVAACT: Hordeum vulgare aluminium-activated citrate transporter; HVMATE: Hordeum vulgare multidrug and toxin extrusion; TaALMT: Wheat aluminium-activated malate transporter; SCAACT1: Secale cereal aluminium-activated citrate transporter; AtALMT1: Arabidopsis aluminium-activated malate transporter; PCR: Polymerase chain reaction; DH: Doubled-haploid; DArT: Diversity arrays technology; SSCP: Single-strand conformation polymorphism; SNP: Single nucleotide polymorphism; bp: Base pair; Alt: Aluminium tolerance; Pht: Tolerance to low pH; Alp: Tolerance to aluminium and low pH; Alp3: Tolerance to aluminium and low pH 3; UTR: Untranslated region.

\section{Competing interests}

The authors declare that they have no competing interests.

\section{Authors' contributions}

MB participated in DNA sequencing, new marker development, data interpretation and provided the initial draft of the manuscript. JX conducted initial SSR molecular marker and QTL analysis. XZ conducted DarT marker analysis and phenotyping. SB developed the $\mathrm{DH}$ population and phenotyping. GZ participated in data analysis and finalized the paper. MZ conducted phenotyping and data analysis. GPZ, DS and CL participated in experimental design, data interpretation and critical revisions of the paper. All authors read and approved the final manuscript.

\section{Acknowledgement}

This research was supported by the Australian Grain Research and Development Corporation and Natural Science Foundation of China (No. 30828023 \& No.30800681) and Zhejiang Provincial Natural Science Foundation of China (Y3100044). Miao Bian received a scholarship from the University of Tasmania.

\section{Author details}

${ }^{1}$ College of Plant Science and Technology, Huazhong Agricultural University, Wuhan 430070, China. ${ }^{2}$ Agronomy Department, Zhejiang University, Hangzhou, China. ${ }^{3}$ Department of Agriculture \& Food WA, 3 Baron-Hay Court, South Perth, WA 6155, Australia. ${ }^{4}$ Western Australian State Agricultural Biotechnology Centre, Murdoch University, Murdoch, WA 6150, Australia. ${ }^{5}$ Tasmanian Institute of Agriculture, University of Tasmania, P.O. Box 46, Kings Meadows, TAS 7249, Australia.

Received: 20 February 2015 Accepted: 16 July 2015 Published online: 29 July 2015

\section{References}

1. Von Uexkuell HR, Mutert E. Global extent, development and economic impact of acid soils. Plant Soil. 1995;171:1-15.

2. Wang JP, Raman H, Zhang GP, Mendham N, Zhou MX. Aluminium tolerance in barley (Hordeum vulgare L.): physiological mechanisms, genetics and screening methods. J Zhejiang Univ Sci B. 2006;7:769-87.

3. Bian M, Zhou M, Sun D, Li C. Molecular approaches unravel the mechanism of acid soil tolerance in plants. The Crop J. 2013;1:91-104.

4. Mattiello L, Kirst M, da Silva FR, Jorge RA, Menossi M. Transcriptional profile of maize roots under acid soil growth. BMC Plant Biol. 2010;10:196.

5. Hoekenga OA, Vision TJ, Shaff JE, Monforte AJ, Lee GP, Howell SH, et al. Identification and characterization of aluminum tolerance loci in Arabidopsis (Landsberg erecta $\times$ Columbia) by quantitative trait locus mapping. A 
physiologically simple but genetically complex trait. Plant Physiol. 2003;132:936-48.

6. Inostroza-Blancheteau C, Aquea F, Reyes-Diaz M, Alberdi M, ArceJohnson P. Identification of aluminum-regulated genes by CDNA-AFLP analysis of roots in two contrasting genotypes of highbush blueberry (Vaccinium corymbosum L.). Mol Biotechnol. 2011;49:32-41.

7. Eticha D, Zahn M, Bremer M, Yang Z, Rangel AF, Rao IM, et al. Transcriptomic analysis reveals differential gene expression in response to aluminium in common bean (Phaseolus vulgaris) genotypes. Ann Bot. 2010;105:1119-28.

8. Maron LG, Kirst M, Mao C, Milner MJ, Menossi M, Kochian LV. Transcriptional profiling of aluminum toxicity and tolerance responses in maize roots. New Phytol. 2008;179:116-28.

9. Ezaki B, Gardner RC, Ezaki Y, Matsumoto $H$. Expression of aluminum-induced genes in transgenic arabidopsis plants can ameliorate aluminum stress and/or oxidative stress. Plant Physiol. 2000;122:657-66.

10. Ma JF, Ryan PR, Delhaize E. Aluminium tolerance in plants and the complexing role of organic acids. Trends Plant Sci. 2001;6:273-8.

11. Singh D, Chauhan SK. Organic acids of crop plants in aluminium detoxification. Curr Sci. 2011;100:1509-15.

12. Kochian LV, Hoekenga OA, Pineros MA. How do crop plants tolerate acid soils? - Mechanisms of aluminum tolerance and phosphorous efficiency. Annu Rev Plant Biol. 2004;55:459-93.

13. Yang L-T, Qi Y-P, Jiang H-X, Chen L-S. Roles of organic acid anion secretion in aluminium tolerance of higher plants. BioMed Res Int. 2012;2013:16.

14. Foy CD, Chaney RL, White MC. The physiology of metal toxicity in plants. Annu Rev Plant Physiol. 1978;29:511-66.

15. Zhao Z, Ma JF, Sato K, Takeda K. Differential Al resistance and citrate secretion in barley (Hordeum vulgare L.). Planta. 2003;217:794-800.

16. StøLen $\mathrm{O}$, Andersen $\mathrm{S}$. Inheritance of tolerance to low soil pH in barley. Hereditas. 1978:88:101-5.

17. Minella E, Sorrells ME. Inheritance and chromosome location of Alp, a gene controlling aluminum tolerance in 'Dayton' barley. Plant Breed. 1997;116:465-9

18. Raman H, Moroni S, Raman, R, Karakousis A, Read B, Sato K, et. al. A Genomic Region Associated with Aluminium Tolerance in Barley. Proceedings of the 10th Australian Barley Technical Symposium. http://www.regional.org.au/au/abts/2001/t3/raman.htm. 2001.

19. Raman H, Moroni J, Sato K, Read B, Scott B. Identification of AFLP and microsatellite markers linked with an aluminium tolerance gene in barley (Hordeum vulgare L.). Theor Appl Genet. 2002;105:458-64.

20. Ma JF, Nagao S, Sato K, Ito H, Furukawa J, Takeda K. Molecular mapping of a gene responsible for Al-activated secretion of citrate in barley. J Exp Bot. 2004:55:1335-41.

21. Furukawa J, Yamaji N, Wang H, Mitani N, Murata Y, Sato K, et al. An aluminumactivated citrate transporter in barley. Plant Cell Physiol. 2007;48:1081-91.

22. Wang J, Raman H, Zhou M, Ryan P, Delhaize E, Hebb D, et al. High-resolution mapping of the Alp locus and identifcation of a candidate gene HVMATE controlling aluminium tolerance in barley (Hordeum vulgare L.). Theor Appl Genet. 2007;115:265-76.

23. Varshney RK, Marcel TC, Ramsay L, Russell J, Roder MS, Stein N, et al. A high density barley microsatellite consensus map with 775 SSR loci. Theor Appl Genet. 2007;114:1091-103.

24. Bian M, Waters I, Broughton S, Zhang X-Q, Zhou M, Lance R, et al. Development of gene-specific markers for acid soil/aluminium tolerance in barley (Hordeum vulgare L.). Mol Breed. 2013;32:155-64.

25. Fujii M, Yokosho K, Yamaji N, Saisho D, Yamane M, Takahashi H, et al. Acquisition of aluminium tolerance by modification of a single gene in barley. Nat Commun. 2012;3:713.

26. Lidon FC, Barreiro MG, Ramalho JC, Lauriano JA. Effects of aluminum toxicity on nutrient accumulation in maize shoots: Implications on photosynthesis. J Plant Nutr. 1999;22:397-416.

27. Pan J-w, Zhu M-y. Chen H. Aluminum-induced cell death in root-tip cells of barley. Environ Exp Bot. 2001;46:71-9.

28. Kidd PS, Proctor J. Why plants grow poorly on very acid soils: are ecologists missing the obvious? J Exp Bot. 2001;52:791-9.

29. Nguyen $V T$, Nguyen $B D$, Sarkarung $S$, Martinez $C$, Paterson $A H$, Nguyen $H T$. Mapping of genes controlling aluminum tolerance in rice: Comparison of different genetic backgrounds. Mol Genet Genomics. 2002;267:772-80.

30. Nguyen BD, Brar DS, Bui BC, Nguyen TV, Pham LN, Nguyen HT. Identification and mapping of the QTL for aluminum tolerance introgressed from the new source, Oryza rufipogon Griff., into indica rice (Oryza sativa L.). Theor Appl Genet. 2003;106:583-93.

31. Famoso AN, Zhao K, Clark RT, Tung CW, Wright MH, Bustamante C, et al. Genetic architecture of aluminum tolerance in rice (Oryza sativa) determined through genome-wide association analysis and QTL mapping. PLoS Genet. 2011;7:e1002221.

32. Ninamango-Cárdenas F, Teixeira Guimarães C, Martins P, Netto Parentoni S, Portilho Carneiro N, Lopes M, et al. Mapping QTLs for aluminum tolerance in maize. Euphytica. 2003;130:223-32.

33. Zhang $X G$, Jessop RS, Ellison F. Inheritance of root regrowth as an indicator of apparent aluminum tolerance in triticale. Euphytica. 1999;108:97-103.

34. Sasaki T, Yamamoto Y, Ezaki B, Katsuhara M, Ahn SJ, Ryan PR, et al. A wheat gene encoding an aluminum-activated malate transporter. The Plant J. 2004;37:645-53.

35. Singh D, Choudhary AK. Inheritance pattern of aluminum tolerance in pea. Plant Breed. 2010;129:688-92

36. Singh D, Raje RS. Genetics of aluminium tolerance in chickpea (Cicer arietinum). Plant Breed. 2011;130:563-8.

37. Collins NC, Shirley NJ, Saeed M, Pallotta M, Gustafson JP. An ALMT1 gene cluster controlling aluminum tolerance at the Alt4 locus of rye (Secale cereale L.). Genet. 2008:179:669-82.

38. Navakode S, Weidner A, Varshney R, Lohwasser U, Scholz U, Börner A. A QTL analysis of aluminium tolerance in barley, using gene-based markers. Cereal Res Commun. 2009;37:531-40.

39. Li HB, Kilian A, Zhou MX, Wenzl P, Huttner E, Mendham N, et al. Construction of a high-density composite map and comparative mapping of segregation distortion regions in barley. Mol Genet Genomics. 2010;284:319-31.

40. Raman H, Karakousis A, Moroni JS, Raman R, Read BJ, Garvin DF, et al. Development and allele diversity of microsatellite markers linked to the aluminium tolerance gene Alp in barley. Aust J Agric Res. 2003;54:1315-21.

41. Silva-Navas J, Benito C, Téllez-Robledo B, Abd El-Moneim D, Gallego F. The SCAACT1 gene at the Qalt5 locus as a candidate for increased aluminum tolerance in rye (Secale cereale L.). Mol Breed. 2011:1-12.

42. Kobayashi Y, Hoekenga OA, Itoh H, Nakashima M, Saito S, Shaff JE, et al. Characterization of AtALMT1 expression in aluminum-inducible malate release and its role for rhizotoxic stress tolerance in arabidopsis. Plant Physiol. 2007;145:843-52.

43. Maron LG, Pineros MA, Guimaraes CT, Magalhaes JV, Pleiman JK, Mao C, et al. Two functionally distinct members of the MATE (multi-drug and toxic compound extrusion) family of transporters potentially underlie two major aluminum tolerance QTLs in maize. Plant J. 2010;61:728-40.

44. Sasaki T, Ryan PR, Delhaize E, Hebb DM, Ogihara Y, Kawaura K, et al. Sequence upstream of the wheat (Triticum aestivum L.) ALMT1 gene and its relationship to aluminum resistance. Plant Cell Physiol. 2006;47:1343-54.

45. Maron LG, Guimaraes CT, Kirst M, Albert PS, Birchler JA, Bradbury PJ, et al. Aluminum tolerance in maize is associated with higher MATE1 gene copy number. Proc Natl Acad Sci. 2013;110:5241-6.

46. Schaefer C, Rost B. Predict impact of single amino acid change upon protein structure. BMC Genomics. 2012;13.

47. Choi $Y$, Sims GE, Murphy S, Miller JR, Chan AP. Predicting the functional effect of amino acid substitutions and indels. PLoS One. 2012;7.

48. Doyle MR, Amasino RM. A single amino acid change in the enhancer of zeste ortholog CURLY LEAF results in vernalization-independent, rapid flowering in Arabidopsis. Plant Physiol. 2009;151:1688-97.

49. Chono M, Honda I, Zeniya H, Yoneyama K, Saisho D, Takeda K, et al. A semidwarf phenotype of barley uzu results from a nucleotide substitution in the gene encoding a putative brassinosteroid receptor. Plant Physiol. 2003;133:1209-19.

50. Yang XQ, Westcott $S$, Gong X, Evans E, Zhang XQ, Lance RCM, et al. Amino acid substitutions of the limit dextrinase gene in barley are associated with enzyme thermostability. Mol Breed. 2009;23:61-74.

51. Maroof MAS, Biyashev RM, Yang GP, Zhang Q, Allard RW. Extraordinarily polymorphic microsatellite DNA in barley - species-diversity, chromosomal locations, and population-dynamics. Proc Natl Acad Sci USA. 1994;91:5466-70.

52. Becker J, Heun M. Mapping of digested and undigested random amplified microsatellite polymorphisms in barley. Genome. 1995;38:991-8.

53. Liu ZW, Biyashev RM, Maroof MAS. Development of simple sequence repeat DNA markers and their integration into a barley linkage map. Theor Appl Genet. 1996:93:869-76. 
54. Struss D, Plieske J. The use of microsatellite markers for detection of genetic diversity in barley populations. Theor Appl Genet. 1998;97:308-15.

55. Cardle L, Ramsay L, Milbourne D, Macaulay M, Marshall D, Waugh R. Computational and experimental characterization of physically clustered simple sequence repeats in plants. Genetics. 2000;156:847-54.

56. Pillen K, Binder A, Kreuzkam B, Ramsay L, Waugh R, Forster J, et al. Mapping new EMBL-derived barley microsatellites and their use in differentiating German barley cultivars. Theor Appl Genet. 2000;101:652-60.

57. Ramsay L, Macaulay M, Ivanissevich SD, MacLean K, Cardle L, Fuller J, et al. A simple sequence repeat-based linkage map of barley. Genet. 2000;156:1997-2005.

58. Li JZ, Sjakste TG, Roder MS, Ganal MW. Development and genetic mapping of 127 new microsatellite markers in barley. Theor Appl Genet. 2003;107:1021-7.

59. Thiel T, Michalek W, Varshney RK, Graner A. Exploiting EST databases for the development and characterization of gene-derived SSR-markers in barley (Hordeum vulgare L.). Theor Appl Genet. 2003;106:411-22.

60. Rostoks N, Mudie S, Cardle L, Russell J, Ramsay L, Booth A, et al. Genome-wide SNP discovery and linkage analysis in barley based on genes responsive to abiotic stress. Mol Genet Genomics. 2005;274:515-27.

61. Savov A, Angelicheva D, Jordanova A, Eigel A, Kalaydjieva L. High percentage acrylamide gels improve resolution in Sscp analysis. Nucleic Acids Res. 1992;20:6741-2.

62. Martins-Lopes P, Zhang H, Koebner R. Detection of single nucleotide mutations in wheat using single strand conformation polymorphism gels. Plant Mol Biol Report. 2001;19:159-62.

63. Kosambi DD. The estimation of map distances from recombination values. Ann Hum Genet. 1943;12:172-5.

64. Manly KF. A Macintosh program for storage and analysis of experimental genetic mapping data. Mamm Genome. 1993;4:303-13.

65. Li H, Ye G, Wang J. A modified algorithm for the improvement of composite interval mapping. Genet. 2007;175:361-74.

66. Li H, Hearne S, Banziger M, Li Z, Wang J. Statistical properties of QTL linkage mapping in biparental genetic populations. Heredity. 2010;105:257-67.

\section{Submit your next manuscript to BioMed Central and take full advantage of:}

- Convenient online submission

- Thorough peer review

- No space constraints or color figure charges

- Immediate publication on acceptance

- Inclusion in PubMed, CAS, Scopus and Google Scholar

- Research which is freely available for redistribution 